\title{
ПРОФІЛАКТИКА ПЛАЦЕНТАРНОЇ ДИСФУНКЦІЇ У ЖІНОК, ЯКІ ПЕРЕНЕСЛИ ПРЕГРАВІДАРНЕ ОПЕРАТИВНЕ ЛІКУВАННЯ ЯЄЧНИКІВ
}

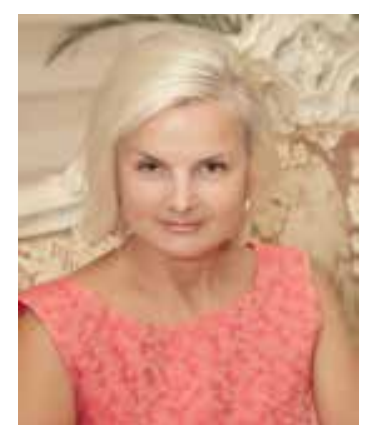

С.Р. ГАЛИЧ

д.мед.Н., просресор кафредри акушерства та гінекологї № 1 Одеського національного медичного університету

\section{О.М. КАЛАНЖОВА} кафредра акушерства та гінекології № 1 Одеського національного медичного університету

\section{О.Ю. МАЛАКАНОВА}

кафедра акушерства та гінекології № 1 Одеського національного медичного університету $\prod_{3}$ ухлиноподібні ураження яєчників у жінок зустрічаються практично в будь-якому віці, однак найчастіше в активних для яєчників періодах - статевого дозрівання та в репродуктивному [4]. Так, за даними літератури, 25-30\% пацієнток репродуктивного віку до настання бажаної вагітності мають в анамнезі лапаротомні або малоінвазивні лапароскопічні операції на яєчниках. Слід зазначити, що у переліку доброякісної патології яєчників новоутворення посідають провідне місце серед показань до хірургічного методу їх лікування у жінок фертильного віку.

У свою чергу підвищення частоти пухлиноподібної патології яєчників за останні 10 років 3 6-10 до 19-25\% та щорічний (в середньому на 5\%) її приріст викликають інтерес сучасних науковців до вивчення репродуктивного здоров'я жінок після прегравідарного оперативного лікування яєчників [3].

Численні дослідження свідчать, що наслідком успішного прегравідарного оперативного лікування яєчників $€$ настання вагітності високого ризику, і це ставить перед фрахівцями подальші завдання забезпечення сприятливого ії̈ перебігу та народження здорової дитини [6].

Так, одним із найбільш частих ускладнень гестаційного процесу у пацієнток, які прегравідарно перенесли операції на яєчниках, вважається плацентарна дисфункція. За даними літератури, розповсюдженість зазначеного ускладнення на фоні прооперованих до вагітності яєчників сягає 73-82\% при значно нижчих загальних популяційних показниках (15-25\%). А зумовлена нею частота перинатальних втрат становить 40-50\% при відносно високому показнику перинатальної захворюваності - 70-75\%。 [2].

На думку сучасних дослідників, характерна для пухлиноподібних уражень яєчників запальна патологія ендометрія, його аутоімунна агресія та характерні локальні порушення рецепторного апарату прогестерону у матці призводять до порушень імплантації, нідації та плацентації $[4,7]$. Це в свою чергу створює підгрунтя для розвитку у пацієнток з оперованими в анамнезі яєчниками плацентарної дисфункції, що має ранні клінічні прояви, стійкий характер перебігу та тенденцію до прогресування [6].

Незважаючи на удавану логічність застосування диференційованих, етіо- та патогенетично обгрунтованих підходів до профрілактики та лікування плацентарної дисфункції у жінок, які перенесли прегравідарне оперативне лікування яєчників, у доступній літературі відсутні чіткі рекомендації щодо даної проблеми. У той же час все це диктує необхідність розробки і упровадження в клінічну практику акушерівгінекологів обгрунтованих, раціональних та ефрективних методів профілактики плацентарної дисфункції.

Мета дослідження полягала в оцінці ефективності використання натурального мікронізованого прогестерону у профілактиці плацентарної дисфрункції у жінок, які перенесли прегравідарне оперативне лікування яєчників.

\section{МАТЕРІАЛИ ТА МЕТОДИ ДОСЛІДЖЕННЯ}

Для вивчення цього питання було здійснено проспективне дослідження перебігу вагітності за участю 60 пацієнток. Основну (I) групу становили 20 вагітних, які перенесли прегравідарне оперативне лікування яєчників та з 8-го до 10-го тижня гестації отримували натуральний мікронізований прогестерон інтравагінально дозою 200 мг/доб протягом 14 днів. До групи порівняння (II) увійшли 20 пацієнток, яким було проведено аналогічне лікування яєчників, але їм не призначали прогестерон. Контрольну групу (III) становили 20 здорових жінок без ускладненого гінекологічного анамнезу. Усі досліджувані були віком від 21 до 39 років (середній вік 26,0 \pm 3,6 року), мали одноплідну вагітність та народжували вперше. Групи були порівнянні за основними медико-соціальними показниками. Тяжкої екстрагенітальної патології у них не виявлено. Уміст ендогенного прогестерону в сироватці крові вагітних відповідав нормативним значенням. Хворим I і II груп у прегравідарному періоді було виконано оперативне лікування яєчників з приводу фолікулярних, ендометріоїдних та параоваріальних кіст.

Визначення клінічних проявів плацентарної дисорункції у групах спостереження проводилося в динаміці вагітності за допомогою ехографії (фетометрія, плацентометрія, вимірювання індексу амніотичної рідини, визначення локалізації плаценти) та доплерометрії. Вивчення доплерометричних показників матково-плацентарно-плодового кровотоку (МППК) у досліджуваних осіб починали проводити з 16-18-го тижня вагітності. Повторну оцінку здійснювали на 28-30-й та 36-38-й тиждень гестації. 
Виявлення тих чи інших гемодинамічних порушень у фетоплацентарному комплексі (ФПК) у зазначені строки гестації зумовлювало додаткове проведення доплерометричних досліджень $з$ метою уточнення діагнозу та розробки адекватної тактики подальшого ведення вагітності. Під час доплерометричного дослідження визначали швидкість МППК в судинах: маткових та спіральних артеріях, артеріях пуповини, середній мозковій артерії плода. Для якісного аналізу стану кровотоку обчислювали індекси судинного опору: систоло-діастолічне співвідношення, індекс резистентності та пульсаційний індекс. Отримані результати інтерпретували за класифрікацією порушень МППК А.Н. Стрижакова та співавт. (1989) [5], статистично обробляли, використовуючи критерій Ст'юдента, та визначали мінімальний (досягнутий) рівень достовірності (р). Різницю між показниками вважали статистично значущою при $р<0,05$ [1].

\section{РЕЗУЛЬТАТИ ДОСЛІДЖЕННЯ \\ ТА ЇХ ОБГОВОРЕННЯ}

Клінічна оцінка гестаційного процесу показала, що блювота вагітних легкого ступеня ускладнила перебіг гестаційного процесу у 13 (65\%) пацієнток I групи та у 12 (60\%) - II групи, що становило достовірну різницю з цим ускладненням у III групі - чотири $(20 \%)$ випадки $(p<0,05)$. Загроза переривання вагітності в I триместрі була констатована у семи (35\%) пацієнток I групи та у 13 (65\%) - II групи $(p<0,05)$. У III групі випадків загрози переривання вагітності в зазначений термін не виявлено. Показник виникнення загрози переривання вагітності в II триместрі у пацієнток I групи (три жінки, 15\%) та III - (три жінки, 15\%) достовірно не розрізнявся $(p>0,05)$. У той же час у II групі його значення було достовірно вищим від двох попередніх груп і становило дев'ять (45\%) випадків ( $<<0,05)$. У III триместрі основним ускладненням вагітності серед жінок із прегравідарним оперативним лікуванням яєчників була прееклампсія. Так, прееклампсія легкого та середньотяжкого ступеня ускладнила перебіг вагітності у восьми (40\%) пацієнток I групи та дев'яти $(45 \%)$ - II групи ( $>0,05)$. Разом із тим у жінок III групи частота прееклампсії виключно легкого ступеня становила лише два $(10 \%)$ випадки $(p<0,05)$.

Ехографрічні прояви плацентарної дисфункції визначались у восьми (40\%) пацієнток I групи та у $15(75 \%)$ - II групи $(\mathrm{p}<0,05)$. Серед жінок III групи випадків клінічних проявів плацентарної дисфункції не спостерігалося. Для вагітних I групи були характерними виключно ізольовані клінічні прояви плацентарної дисфункції: у двох (10\%) жінок у вигляді помірного маловоддя, у трьох (15\%) - синдрому затримки росту плода (СЗРП) І ступеня на фоні гіпертрофії плаценти (три випадки, 15\%), що свідчило про переваж- но компенсований стан ФПК. У вагітних II групи прояви плацентарної дисфункції були виразнішими і полягали у поєднанні СЗРП І ступеня з гіпотрофрією плаценти (п'ять випадків, 25\%), СЗРП I ступеня з маловоддям та гіпертрофією плаценти (три випадки, 15\%), СЗРП ІІ ступеня із маловоддям (два випадки, 10\%), СЗРП ІІ ступеня з гіпотрофрією плаценти (чотири випадки, 20\%), СЗРП ІІ ступеня з гіпертрофією плаценти та багатоводдям (один випадок, $5 \%$ ).

При цьому умови плацентації у вагітних обох основних груп були однаково несприятливими. Локалізація плаценти по передній стінці тіла матки визначалась у семи жінок (35\%) I групи та у п'яти (25\%) - II групи; по боковій стінці - у шести (30\%) жінок I групи та у п'яти (25\%) - II групи; низька плацентація - відповідно у семи (35\%) та у трьох (15\%) випадках $(p<0,05)$. Найбільш сприятливе розташування плаценти по передній стінці матки відмічалось у переважної кількості пацієнток III групи (18 жінок, 90\%) та у деяких пацієнток II групи (сім випадків, 25\%). На наш погляд, саме застосування прогестерону, який покращує кровоплин у міжворсинчастому просторі, сприяло мінімізації фрормування плацентарної диссрункції у пацієнток I групи, незважаючи на переважно несприятливе розташування в них плаценти.

На основі доплерометричних досліджень було встановлено, що для жінок, які перенесли прегравідарне оперативне лікування яєчників, характерні ранні порушення МППК. При цьому на 16-18-му тижні гестації гемодинамічні порушення, що мали виключно ізольований характер (IA або IB ступінь), достовірно частіше реєструвалися серед пацієнток II групи. Так, IA ступінь порушення визначався у п'яти (25\%) жінок, IB - в однієї (5\%) - II групи, тоді як в I групі IA ступінь виявлено лише у трьох $(15 \%)$ осіб ( $<$ 0,05). У пацієнток III групи не було діагностовано жодного випадку гемодинамічних порушень ФПК $(p<0,05)$.

Гестаційна підтримка прогестероном виявилася доцільною з огляду на різну частоту прогресування порушень МППК в основній та групі порівняння. Так, на 28-30-му тижні вагітності у восьми (40\%) пацієнток I групи гемодинамічні порушення мали виключно ізольований характер, $з$ яких сім (35\%) належали до IА ступеня порушень та одне (5\%) - до IB ступеня. Про несприятливий стан МППК пацієнток II групи свідчили: кількість випадків МППК (15 жінок, 75\%) та структура гемодинамічних порушень (IА ступінь - 2 (10\%) випадки, ІВ ступінь - 9 (45\%) випадків, ІІ ступінь - 4 (20\%) випадки) $($ р < 0,05). Серед пацієнток III групи в цей строк гестації реєструвалися виключно ізольовані гемодинамічні порушення МППК - два (10\%) випадки ІА ступеня.

Загальна кількість гемодинамічних порушень МППК як в I групі, так і в II залишалася незмінною

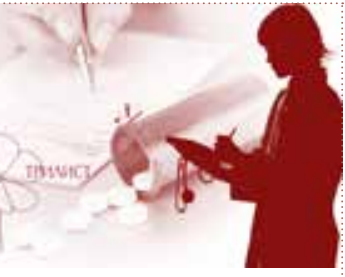

Застосування прогестерону покращує кровоплин у міжворсинчастому просторі, що сприяє мінімізації формування плацентарної дисфункції, незважаючи на несприятливе розташування плаценти 


\begin{tabular}{|c|c|c|c|c|c|c|}
\hline \multirow{3}{*}{$\begin{array}{c}\text { АБЛИЦЯ } \\
\text { Порушен- } \\
\text { ня МППК, } \\
\text { ступінь }\end{array}$} & & & & & & \\
\hline & \multicolumn{2}{|c|}{$\begin{array}{l}\text { I група } \\
(\mathrm{n}=20)\end{array}$} & \multicolumn{2}{|c|}{$\begin{array}{l}\text { II група } \\
(n=20)\end{array}$} & \multicolumn{2}{|c|}{$\begin{array}{l}\text { III група } \\
(\mathrm{n}=20)\end{array}$} \\
\hline & абс. & $\%$ & абс. & $\%$ & абс. & $\%$ \\
\hline \multicolumn{7}{|c|}{ 16-18 тиж } \\
\hline $\begin{array}{l}\text { IA } \\
\text { IB }\end{array}$ & $\begin{array}{l}3^{*} \\
0\end{array}$ & $\begin{array}{c}15,0 \\
0\end{array}$ & $\begin{array}{l}5^{*} * * \\
1^{*} * *\end{array}$ & $\begin{array}{c}25,0 \\
5,0\end{array}$ & $\begin{array}{l}0 \\
0\end{array}$ & $\begin{array}{l}0 \\
0\end{array}$ \\
\hline \multicolumn{7}{|c|}{ 28-30 тиж } \\
\hline IA & $7^{*}$ & 35,0 & $2^{* *}$ & 10,0 & 2 & 10,0 \\
\hline IB & $1^{*}$ & 5,0 & $9^{*} \star *$ & 45,0 & 0 & 0 \\
\hline ॥ & 0 & 0 & $4^{* * *}$ & 20,0 & 0 & 0 \\
\hline \multicolumn{7}{|c|}{ 36-38 тиж } \\
\hline IA & $4^{* * *}$ & 20,0 & 0 & 0 & 3 & 15,0 \\
\hline IB & $4^{*} * *$ & 20,0 & $6^{* * *}$ & 30,0 & 0 & 0 \\
\hline ॥ & 0 & 0 & $9^{*} * *$ & 45,0 & 0 & 0 \\
\hline
\end{tabular}

ТАБлИЦЯ.

ПОРУШЕННЯ МППК У ГРУПАХ СПОСТЕРЕЖЕННЯ

* $p<0,05$ порівняно

3 III групою

** $p<0,05$ у порівнянні між I та || групами

\section{ВИСНОВКИ}

1. Застосування натурального мікронізованого прогестерону інтравагінально добовою дозою 200 мг протягом 14 днів у переважної більшості жінок, які перенесли прегравідарне оперативне лікування яєчників, асоціювалось із нормальними показниками МППК та достовірно меншою кількістю пацієнток (вісім жінок, 40\%), які мали порушення кровотечі виключно ізольованого характеру: IA ступінь мав місце у чотирьох (20\%) жінок, IB у чотирьох $(20 \%)(p<0,05)$.

2. Профрілактика плацентарної дисфункції 3 використанням натурального мікронізованого прогестерону у таких жінок сприяла нижчій частоті розвитку клінічних проявів плацентарної диссрункції: помірного маловоддя (два випадки, 10\%), СЗРП І ступеня (три випадки, 15\%) та гіпертрофії плаценти (три випадки, 15\%) у порівнянні із пацієнтками, які не отримували зазначеної профрілактики $(p<0,05)$.

3. Ефективність натурального мікронізованого прогестерону у профілактиці плацентарної дисфункції підтверджена переважно задовільним станом новонароджених у пацієнток І групи (СЗРП І ступеня виявлено у трьох [15\%] випадках), відсутністю перинатальних втрат і мінімальною частотою морфологічно верифрікованої плацентарної дисфункції (у восьми пацієнток, 40\%) $(p<0,05)$.

4. Отримані дані свідчать про доцільність застосування натурального мікронізованого прогестерону інтравагінально з метою профілактики плацентарної дисфункції у жінок, які перенесли прегравідарне оперативне лікування яєчників.

\section{ЛІТЕРАТУРА}

1. Андронов А.М. Теория вероятности и математическая статистика / А.М. Андронов, Е.А. Копытов, Л.Я. Гринглаз. - СПб.: Питер, 2004. - 460 с.

2. Зарічанська Х.В. Особливості перебігу гестаційного періоду у жінок, які перенесли операцію на придатках матки // Вісник наукових досліджень: Тернопіль, 2005. - 78-79 с.

3. Зейналов С.М. Малоинвазивная хирургия в диагностике и лечении заболеваний придатков матки / С.М. Зейналов, А.С. Кадырова // Эндоскопическая хирургия. - М., 2007. - № 2. - С. 61-63.

4. Кондратюк В.К. Сучасні уявлення щодо патогенетичних механізмів ушкодження репродуктивної системи у жінок з пухлиноподібними ураженнями яєчників // Педіатрія, акушерство та гінекологія. 2006. - № 6. - С. 93-97.

5. Милованов А.П. Патология системы матьплацента-плод. Руководство для врачей. - М.: Медицина, 1999. - 335 с.

6. Носенко О.М. Морфросункцціональні особливості яєчників з наявністю доброякісних кістозних утворень у жінок репродуктивного віку // Здоровье женщины. - 2006. - № 2. - С. 118-126.

7. Рец Ю.В. Прогностическое значение регуляторных и адаптационных процессов в системе мать-плацента-плод в исходе беременности и родов // Вопросы гинекологии, акушерства и перинатологии. 2008. - № 2. - C. 18-27. 